\title{
Analysis of Circumstances and Causes of Accidents Working in a Selected Industrial Undertaking
}

\author{
Michał Pałęga, Marcin Knapinski \\ Czestochowa University of Technology, Poland
}

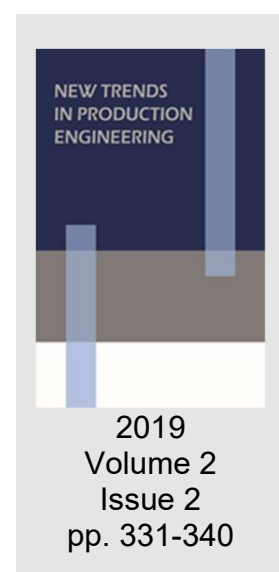

Date of submission to the Editor: 09/2019

Date of acceptance by the Editor: 11/2019

\section{INTRODUCTION}

According to Polish legal regulations (Journal of Laws of 2018, item 917), one of the basic duties of the employer is to provide employees with conditions for safe and hygienic work and taking measures to prevent accidents and illnesses related to work. In practice, these duties should be implemented through: (Journal of Laws of 2003 No. 169, item 1650, as amended)

- risk prevention;

- carrying out risk assessment related to hazards that cannot be completely eliminated;

- eliminating threats at the source of their occurrence;

- adjusting work conditions and processes to the employee's abilities, in particular through appropriate design and organization of workplaces, selection of machines and other technical equipment and tools, as well as production methods and work - taking into account the reduction of work nuisance, especially monotonous work and work in a fixed advance rate and limit the negative impact of such work on the health of employees,

- applying new technical solutions;

- replacing dangerous technological processes, devices, substances and other materials - safe or less safe;

- giving priority to collective protection measures against personal protection measures;

- instructing employees regarding occupational health and safety.

In addition, it should be pointed out that ensuring safety at the workplace requires undertaking specific activities related to accident prevention, preceded by a meticulous assessment of occupational risk and analysis of accidents at work (Figure 1). Therefore, the issue of work-related breaks is extremely important, and the deepening of the subject matter is necessary and fully justified (Cheng et al., 2010, Pietilä et al., 2018, Pietrzak, 2007). 


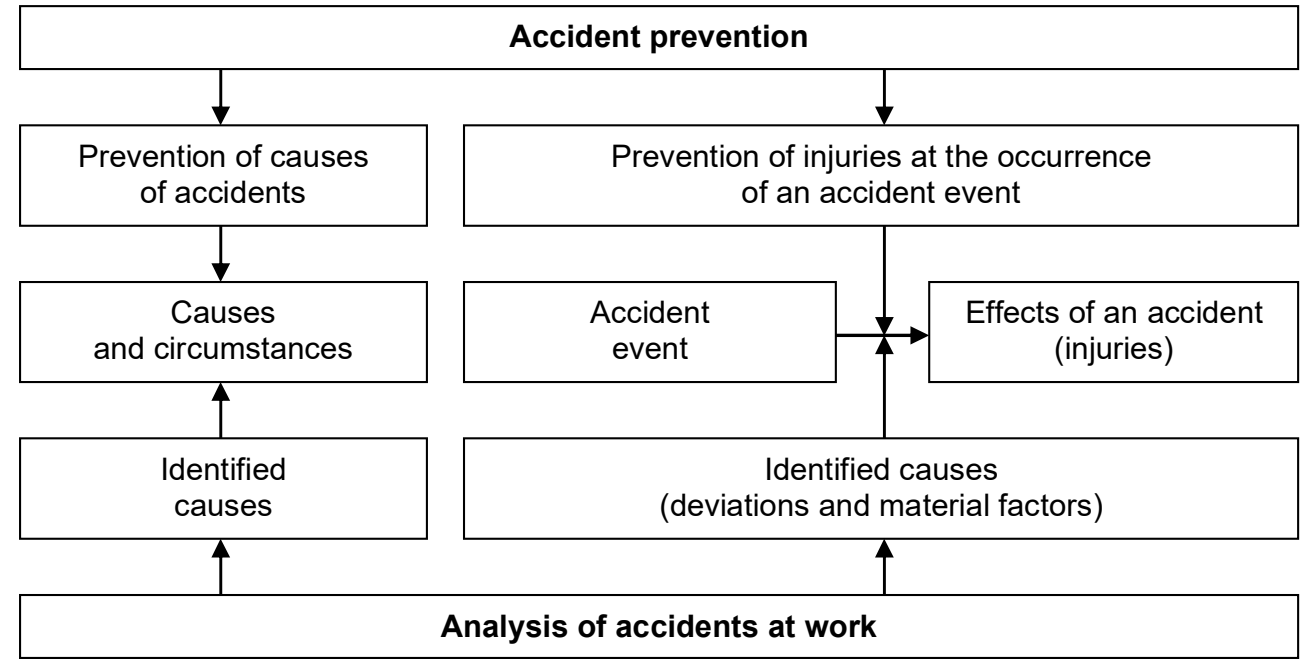

Source: (Pietrzak, 2007)

Fig. 1 Accident prevention

This publication has a theoretical and empirical nature. As part of the study of literature, the statutory definition of an accident at work and its classification were presented. All four conditions were discussed, which should exist at the same time, to classify a specific event as an accident at work, i.e.: the suddenness of an event, external cause, injury and relation to work. Next, it was emphasized how important role in ensuring work safety is to examine the circumstances and causes of the accident and characterize one of the most commonly used methods, which is the TOL method, which takes into account three types of reasons: technical, organizational and human. In turn, the authors' own research focused on the analysis of accidents at work in a selected industrial enterprise that provides water and laser cutting services. The paper presents the basic requirements for the waterjet operator's position, as well as examples of hazards that may cause accidents. The essential part of the work is to present the results of the analysis of the circumstances and causes of accidents at work. In the period from 2013 to 2018, eight accidents were recorded in the waterjet operator position, resulting in minor injuries, such as cut wounds, fracture of the phalanx, twisting of the leg or knee injury. Laser cut-off operators as well as administrative and office employees were excluded from the analysis, as no work-related accident was noted at these positions.

\section{ACCIDENT AT WORK AND ITS CLASSIFICATION}

The accident act (Journal of Laws 2002 No. 199, item 1673) defines an accident at work as an event: sudden, caused by an external cause, causing injury or death, which occurred in connection with the work performed. The simultaneous appearance of all four conditions indicated above allows to qualify a specific event as an accident at work. Lack of even one of the mentioned elements prevents recognition of an incident as an accident at work. A synthetic analysis of the abovementioned trauma at work (www.pip.gov.pl/pl/bhp/wypadek-przypracy/wypadki-zwiazane-z-praca/6444,-wypadek przy-pracy-przepisyprawne.html). 
Suddenness - means the immediate occurrence of an external cause that produces a specific effect; The Polish jurisprudence also adopted the view that the duration of the action of a specific factor causing an accident cannot exceed one working day. Nevertheless, the time period should be treated flexibly, bearing in mind that the employee may provide overtime (which should also be treated as the suddenness of the event); suddenness is a feature that determines the qualification of a given event as an accident at work (as opposed to an occupational disease).

External cause - occurs when the injury is a consequence of external factors influencing the employee. The external cause can also be treated as actions performed by the injured person, such as increased physical or mental workrelated exertion.

Injury - damage to tissues of the body or human organs due to external factors (dangerous). In a situation where there is a sudden event caused by an external cause and related to the work performed, but as a consequence not causing an injury, it is referred to as an accidental atraumatic event.

Relationship with work - occurs when an accident (injury) occurs while the employee performs official duties or is at the disposal of the employer, in particular: (Journal of Laws 2002 No. 199, item 1673)

- during or in connection with the employee's performance of ordinary activities or orders of his superiors;

- during or in connection with the employee performing activities for the benefit of the employer, even without instructions;

- while the employee is at the disposal of the employer on the way between the employer's seat and the place of performing the obligation resulting from the employment relationship.

There are four types of accidents at work: heavy, fatal, light and collective (http://archiwum.ciop.pl/22608.html

Winge, Albrechtsen,2016, www.pip.gov.pl/pl/bhp/wypadek-przy-pracy/wypadkizwiazane-z-praca/6444,-wypadek przy-pracy-przepisy-prawne.html)

Heavy accident - an accident, resulting in inability to work over 28 days and an accident that resulted in serious bodily injury (e.g. loss of sight, hearing, speech, ability to beget or other serious damage). An accident is also considered to be a serious accident, the consequences of which cause an incurable or lifethreatening illness, permanent mental illness, as well as permanent and total inability to work in the profession or permanent, serious disfigurement or deformation of the body.

Fatal accident - an accident that resulted in death at the scene of the accident or within 6 months from the occurrence of the event.

A light accident - an accident that does not exhaust the signs of a serious or fatal accident.

Collective accident - means an accident which, as a result of the same event (e.g. fire, explosion), at least two people have been killed. 


\section{DETERMINATION OF ACCIDENTS AT WORK WITH THE TOL METHOD}

Accidents are complex events resulting from the combination of many factors of a technical, environmental, organizational and human nature. In the process of explaining the causes of accidents, it is necessary to determine non-compliance with the occupational health and safety standards adopted in the company ( $\mathrm{Li}$, Guldenmund, 2018), Yoon et al., 2013). The purpose of an accident investigation is to identify the causes and circumstances of accidents, i.e. determine what happened and why. Investigation of accidents should lead to establishing facts related to what happened before the accident, as the event occurred and which ultimately led to an employee injury (Zhang et al., 2016). In addition, a thorough study should enable action to be taken to prevent similar accidents at work in the future, in particular by eliminating or reducing the risks that triggered the accident (Jabbari, Ghorbani, 2016, Pietrzak, 2014).

One of the most commonly used methods of studying accidents at work is the TOL analysis. It is based on the assumption that the causative reasons of the accident should be seen in the following factors: (Pietrzak, 2003)

- material-technical (T);

- organizational (O);

- human (L).

In accordance with the above classification, technical reasons may result from the use of improper technology, improper construction of machines, tools and devices, poor technical condition of safety devices, defects and improper condition of the product, material or substance, etc. In particular, technical reasons include: (Statistical Accident Card Z-KW)

- inadequate condition of the material factor;

- design defects or improper technical and ergonomic solutions of the material factor;

- improper implementation of the material factor;

- material defects of the material factor;

- improper use of the material factor.

Organizational reasons concern threats resulting from the broadly understood organization of work and production in the enterprise (general organization of work) and at the workplace. They include: (Statistical Accident Card Z-KW)

- inappropriate general work organization;

- improper workplace organization.

The third category of causes in the TOL systematics are human causes. These reasons are related to incorrect conduct or reaction of employees, as well as indirect participants in hazardous activities. The group of human causes in the statistical accident card consists of such reasons as: (Statistical Accident Card Z-KW)

- lack or improper handling of the material factor by the employee;

- failure to use protective equipment by an employee;

- inappropriate arbitrary behavior of the employee; 
- psychophysical condition of the employee, which does not ensure safe work due to:

- sudden illness, physical disability

- chronic or acute mental illness

- fatigue

- nervousness

- consumption of alcohol, narcotic drugs or psychotropic substances

- other reasons

- incorrect employee behavior due to:

- ignorance of the threat

- ignorance of the rules and principles of health and safety at work

- disregarding the threat (bravado, hazard)

- disregarding the instructions of the superiors

- insufficient focus on the activity performed

- surprise by an unexpected event

- improper work pace

- lack of experience

- other reasons.

When conducting an accident investigation, they are analyzed in the following order: technical and organizational reasons as well as those caused by a man, which in effect allows to determine the indirect causes of the accident. It is also important to establish connections between different groups of causes. Recognizing the causes of an accident can also be extended to other groups, depending on the type and specificity of the event (e.g. working environment, work process, tasks and tasks, management).

\section{SUBJECT AND TRADER OF THE RESEARCH}

The subject of the research is to analyze the circumstances and causes of accidents at work as a water-cutting operator in a selected company.

The research facility is a company operating since 2003 in the provision of waterjet and laser cutting services, as well as bending on a press brake and cutting, cutting rollers and profiles on a band saw. The analyzed company is located in the country and performs orders for both small and large business entities as well as individual (retail) clients.

\section{RESULTS}

\section{Characteristics of the waterjet operator's work station}

The operator's station is located in a production hall with cubic dimensions: length $-30 \mathrm{~m}$; width $-12 \mathrm{~m}$; height $-9 \mathrm{~m}$. The object is heated by a central heating installation and meets the requirements for minimum temperatures at physical workplaces. The place of work is illuminated by daylight through the trained surfaces of the walls and in the ceiling. Additional lighting is provided by fluorescent lamps. The floor is even, uncluttered, dust-free and without any frets 
between the rooms. Employees have access to full sanitary and hygienic facilities.

A person employed as a water-cutting operator should be at least 18 years of age and have lower secondary or secondary vocational education (not necessarily major). It is also welcome that the candidate should have additional rights, for example, permission to ride a forklift truck, operating a crane, or energy entitlements up to $1 \mathrm{kV}$.

The work of a laser cutting machine operator consists in performing activities related to cutting a wide range of materials such as: steels, non-ferrous metals, stone, ceramics, rubber, plastics, glass and special materials. It takes place in a shift cycle, 8 hours for a work shift. The employee performs the activities in accordance with the established process. His basic tasks and duties include: (Material of the company under study)

- preparation of the station and equipment for work according to the station instructions;

- transporting material to the cutting plotter table (manually or mechanically);

- correct embedding in the template or fixing by clamping;

- entering the received program of performed operations to the control computer;

- supervision over the cutting process (outside the danger zone);

- picking up and transporting the cut objects to the place of storage;

- moving between positions (as needed);

- control of the status of individual machine components, their maintenance and small repairs (in accordance with their knowledge and skills);

- cleaning and organizing the workplace.

The operating environment of the waterjet cutting machine is characterized by the presence of many hazardous and harmful factors. Among them, indicate (Material of the company under study):

- high pressure water jets;

- strong electromagnetic field;

- electric current;

- laser radiation;

- abrasive particles and filings from the material cut;

- noise up to $95 \mathrm{~dB}$;

- static load: forced, standing body position.

Due to the presence of harmful environmental factors, employees are required to comply with the basic principles of occupational health and safety, as well as the use of personal protective equipment. These include hearing protectors, eye protectors (up to $6 \mathrm{~m}$ around the machine), protective clothing, work shoes (with finger guard) and protective gloves. It is also forbidden to wear clothing or other loosely hanging items (e.g. jewellery). In addition, daily cleaning of the area around the machine is advisable. Because the accumulated particles from material cutting and abrasive can cause breathing difficulties and respiratory infections. It is also recommended to use only quartz free abrasives. Quartz and 
other substances contained in the abrasive can lead to damage to the airways. In order to eliminate the risk of slipping, always wipe off any water or oil spilled on the floor, and it is recommended to lay a special rubber mat in front of the machine with drain holes and grooves. An important issue related to the provision of safe working conditions is proper staff training. The machine should only be operated by properly trained employees. Untrained personnel should be treated as unauthorized persons who are not allowed to perform any maintenance or maintenance operations on the machine.

\section{Accidents at work as a water-cutting operator}

The analysis of the state of accidents at work on the waterjet operator's station indicates that these are unit events that additionally do not cause serious bodily injury or death. The effects of accidents at work relate to such injuries as: cuts and cuts, fracture of the phalanx, twisting of the leg, overloading of the spine or eye injury. The causes of these accidents are primarily on the side of organizational and human factors, and are less often related to technical and material factors. Therefore, the main preventive measures include familiarizing employees with the post-accident protocol and carrying out additional job instructions in the scope of correct performance of problematic activities that were the source of an accident at work. The register of accidents at work, taking into account the circumstances and causes of the accident, as well as preventive measures, is presented in Table 1. In the light of the analysis, it should be noted that as a rule, the company's management pays great attention to ensuring safe and hygienic working conditions. This statutory obligation is implemented by undertaking preventive actions, which include systematic identification of potential and actual hazards at the workplace and updating the occupational risk assessment. In addition, it should be pointed out that a significant impact on the safety of the waterjet operator's operation is the type of machine and its equipment with basic safety components. Accurate training and employee awareness are also important in accident prevention. This view is also shared by the company's management team, trying to complement the employee's knowledge in the field of safe machine operation and performing activities at the workplace. Because all mistakes and improper behavior of the employee may result from the lack of his experience at his current job position, or even routine action.

In view of the above, it should be recognized that the water protection measures applied at the operator of the waterjet are effective and do not cause serious accident events. 
Table 1 Analysis of the circumstances and causes of accidents at work as a water-cutting operator

\begin{tabular}{|c|c|c|c|c|}
\hline No. & $\begin{array}{l}\text { The result } \\
\text { of an } \\
\text { accident } \\
\text { (injury) }\end{array}$ & Circumstances & Causes & Preventive actions \\
\hline \multirow[b]{2}{*}{1.} & \multirow[b]{2}{*}{$\begin{array}{l}\text { Injury } \\
\text { of the } \\
\text { right eye }\end{array}$} & \multirow[b]{2}{*}{$\begin{array}{l}\text { The impact } \\
\text { of the metal's } \\
\text { resilience with } \\
\text { a sheet } \\
\text { of waste metal } \\
\text { sheet }\end{array}$} & $\begin{array}{l}\text { A sudden, uncontrolled dislocation } \\
\text { of the material }\end{array}$ & \multirow[b]{2}{*}{$\begin{array}{l}\text { Familiarize employees with the } \\
\text { circumstances and causes of accidents } \\
\text { and post-accident order } \\
\text { Carry out additional job training regarding } \\
\text { proper waste storage }\end{array}$} \\
\hline & & & $\begin{array}{l}\text { Improper storage of waste by } \\
\text { employees of the previous change } \\
\text { Deviation from the norm of the factor } \\
\text { caused by the elastic force } \\
\text { The surprise of the suddenness of an } \\
\text { event }\end{array}$ & \\
\hline \multirow[b]{2}{*}{2.} & \multirow[b]{2}{*}{$\begin{array}{l}\text { Finger } \\
\text { wounds } \\
\text { IV hand } \\
\text { left }\end{array}$} & \multirow[b]{2}{*}{$\begin{array}{l}\text { When sliding } \\
\text { the sheet metal } \\
\text { into the rack }\end{array}$} & $\begin{array}{l}\text { Lack of coordination in the collective } \\
\text { performance of transport work }\end{array}$ & \multirow{2}{*}{$\begin{array}{l}\text { Familiarize employees with the } \\
\text { circumstances and causes of accidents } \\
\text { and post-accident order } \\
\text { Carry out additional job training regarding } \\
\text { transport rules } \\
\text { Give the employee appropriate personal } \\
\text { protection }\end{array}$} \\
\hline & & & $\begin{array}{l}\text { Contact with a sharp object } \\
\text { Loss of control over the subject } \\
\text { Improper selection of personal } \\
\text { protective equipment }\end{array}$ & \\
\hline \multirow[b]{2}{*}{3.} & \multirow[b]{2}{*}{$\begin{array}{l}\text { Head } \\
\text { damage } \\
\text { (contusion, } \\
\text { hematoma) }\end{array}$} & \multirow[b]{2}{*}{$\begin{array}{l}\text { When transporting } \\
\text { pallets } \\
\text { with workpieces } \\
\text { (falling object) }\end{array}$} & Contact with immobile items & \multirow[b]{2}{*}{$\begin{array}{l}\text { Familiarize employees with } \\
\text { the circumstances and causes } \\
\text { of accidents and post-accident order } \\
\text { Carry out additional job training regarding } \\
\text { the protection of materials intended for } \\
\text { transport } \\
\text { Give the employee appropriate personal } \\
\text { protection }\end{array}$} \\
\hline & & & $\begin{array}{l}\text { Incorrect staticity of the material } \\
\text { factor caused by improper storage on } \\
\text { the pallet } \\
\text { Improper protection of the material } \\
\text { factor during transport } \\
\text { Failure by the employee to comply } \\
\text { with health and safety rules } \\
\text { Improper selection of personal } \\
\text { protective equipment }\end{array}$ & \\
\hline \multirow[b]{2}{*}{4.} & \multirow[b]{2}{*}{$\begin{array}{l}\text { Cutting } \\
\text { the left hand }\end{array}$} & \multirow[b]{2}{*}{$\begin{array}{l}\text { When converting } \\
\text { sheet metal }\end{array}$} & Disregarding the threat & \multirow{2}{*}{$\begin{array}{l}\text { Familiarize employees with } \\
\text { the circumstances and causes } \\
\text { of accidents and post-accident order } \\
\text { Order the employee to strictly use } \\
\text { personal protective equipment }\end{array}$} \\
\hline & & & $\begin{array}{l}\text { Not using personal protective } \\
\text { equipment } \\
\text { Inappropriate static of the material } \\
\text { factor caused by improper storage }\end{array}$ & \\
\hline \multirow[b]{2}{*}{5.} & \multirow[b]{2}{*}{$\begin{array}{l}\text { Twisting } \\
\text { the leg }\end{array}$} & \multirow[b]{2}{*}{ While moving } & Employee collapse at the same level & \multirow[b]{2}{*}{$\begin{array}{l}\text { Familiarize employees with the } \\
\text { circumstances and causes of accidents } \\
\text { and post-accident order } \\
\text { Conduct additional training in the area } \\
\text { of the obligation to maintain order and } \\
\text { order at the workplace }\end{array}$} \\
\hline & & & $\begin{array}{l}\text { Slip the employee } \\
\text { Not removing a spilled substance } \\
\text { (water) } \\
\text { Other employee's failure to maintain } \\
\text { order at the workplace }\end{array}$ & \\
\hline \multirow[b]{2}{*}{6.} & \multirow[b]{2}{*}{$\begin{array}{l}\text { Overloading } \\
\text { the spine }\end{array}$} & \multirow[b]{2}{*}{$\begin{array}{l}\text { When pulling } \\
\text { out cut elements }\end{array}$} & $\begin{array}{l}\text { Failure to comply with lifting } \\
\text { standards }\end{array}$ & \multirow{2}{*}{$\begin{array}{l}\text { Familiarize employees with } \\
\text { the circumstances and causes } \\
\text { of accidents and post-accident order } \\
\text { Carry out additional workplace training } \\
\text { regarding the rules of carrying out manual } \\
\text { transport work and lifting standards }\end{array}$} \\
\hline & & & $\begin{array}{l}\text { Accepting the wrong position of the } \\
\text { body } \\
\text { Doing work in too small staffing } \\
\text { Low employee awareness of the } \\
\text { threat }\end{array}$ & \\
\hline \multirow[b]{2}{*}{7.} & \multirow[b]{2}{*}{ Knee injury } & \multirow[b]{2}{*}{$\begin{array}{l}\text { When lowering } \\
\text { the sheet (sharp } \\
\text { edge) }\end{array}$} & $\begin{array}{l}\text { A sudden, uncontrolled dislocation } \\
\text { of the material }\end{array}$ & \multirow{2}{*}{$\begin{array}{l}\text { Familiarize employees with the } \\
\text { circumstances and causes of accidents } \\
\text { and post-accident order } \\
\text { Carry out additional workplace training } \\
\text { for proper gripping and transfer } \\
\text { of the material factor } \\
\text { Determining the scope of work that you } \\
\text { absolutely should not do yourself }\end{array}$} \\
\hline & & & $\begin{array}{l}\text { Direct contact with the sharp edge } \\
\text { of the element } \\
\text { Improper gripping, holding a material } \\
\text { factor } \\
\text { Doing work in too small staffing }\end{array}$ & \\
\hline 8. & $\begin{array}{l}\text { Wounding } \\
\text { the finger } \\
\text { i left hand }\end{array}$ & $\begin{array}{l}\text { When cutting } \\
\text { rubber }\end{array}$ & $\begin{array}{l}\text { Improper operation of the upper limb } \\
\text { in the danger zone }\end{array}$ & $\begin{array}{l}\text { Familiarize employees with } \\
\text { the circumstances and causes } \\
\text { of accidents and post-accident order } \\
\text { Carry out additional workplace training } \\
\text { for safe cutting operations }\end{array}$ \\
\hline
\end{tabular}

\section{CONCLUSION}

On the basis of the literature analysis and the authors' own research, the following conclusions and final statements can be formulated:

1. Every employee, regardless of the type of work performed or preventive measures used at the workplace, is exposed to an accident at work. Usually, these are complex events resulting from the combination of material- 
technical, environmental, organizational and human factors, and in special situations also from random factors (e.g. forces of nature).

2. One of the basic duties of the employer, in the event of receiving information about an accident event, is giving the first aid to the aggrieved party (the aggrieved party), securing the accident site (even against unauthorized access), and carrying out post-accident proceedings. The purpose of such proceedings is to determine the circumstances and causes of an accident at work and to apply appropriate preventive measures that will prevent similar events in the future.

3. The accumulation of the post-accident team on its course and the logical analysis of facts is of crucial importance in the process of accident investigation, and the smaller - searching for the guilty in the face of the identified causes of accidents. For if all attention is focused on seeking guilty, then the causes and prophylactic conclusions can be determined in the right way.

4. In the specialist literature, as well as in the practice of health and safety services, many accident investigation methods are described and applied. One of them is the systematics of TOL, which classifies the causes of accidents according to three basic groups: material-technical, organizational and human factors, without excluding other factors, if necessary.

5. From the initial assessment of the waterjet operator's work position, it appears that there are many risk factors in his environment which include: high pressure water jets, strong electromagnetic field, electric current, laser radiation, abrasive particles and filings from the cut out material, noise in up to $95 \mathrm{~dB}$, as well as the static load caused by a forced, standing body position.

6. The analysis of the state of accidents at work at the waterjet operator's station indicates that these are individual events that cause minor injuries and personal injuries.

7. The conducted research also showed that the main reasons for accidents at work were factors caused by improper work organization or work positions, as well as abnormal staff behaviors (e.g. disregarding the hazard, non-use of personal protective equipment).

8. In the light of the conducted research, it can be stated that working at a waterjet operator station is fairly safe. This does not mean, however, that the management of the company does not take any action to eliminate or limit the level of threats. Because accident prevention at the discussed workplace focuses primarily on organizational activities, in particular training and awareness of employees, as well as the designation and proper marking of hazardous zones.

\section{REFERENCES}

Cheng, C.-W., Leu, S.-S., Lin, C.-C., Fan, C. (2010). Characteristic analysis of occupational accidents at small construction enterprises. Safety Science, 48 (6), pp. 698-707.

http://archiwum.ciop.pl/22608.html 
Jabbari, M., Ghorbani, R. (2016). Developing techniques for cause-responsibility analysis of occupational accidents. Accident Analysis and Prevention. Volume 96, 1 pp. 101-107.

Li, Y., Guldenmund, F.W. (2018). Safety management systems: A broad overview of the literature. Safety Science. Volume 103, pp. 94-123.

Material of the company under study

Pietilä, J., Räsänen, T., Reiman, A., Ratilainen, H., Helander, E. (2018). Characteristics and determinants of recurrent occupational accidents. Safety Science Volume 108, pp. 269-277.

Pietrzak L. (2003). Occupational accident models. Health and safety at work 10/2003. Warsaw: Central Institute for Labor Protection.

Pietrzak L. (2014). Accident at work. Employer's guide. Warsaw: National Labor Inspectorate.

Pietrzak, L. (2007). Analysis of accidents at work for prevention purposes. Warsaw: National Labor Inspectorate.

Regulation of the Minister of Labor and Social Policy of 26 September 1997 on general health and safety at work regulations (Journal of Laws of 2003 No. 169, item 1650, as amended)

Statistical Accident Card Z-KW

The Act of June 26, 1974, the Labor Code (Journal of Laws of 2018, item 917).

The Act of October, 30, 2002 on social insurance for accidents at work and occupational diseases (Journal of Laws 2002 No. 199, item 1673).

Winge, S., Albrechtsen, E. (2018). Accident types and barrier failures in the construction industry. Safety Science. Volume 105, pp. 158-166.

www.pip.gov.pl/pl/bhp/wypadek-przy-pracy/wypadki-zwiazane-z-praca/6444,-wypadek przy-pracy-przepisy-prawne.html

Yoon, S.J., Lin, H.K., Chen, G., Yi, S., Choi, J., Rui, Z. (2013). Effect of occupational health and safety management system on work-related accident rate and differences of occupational health and safety management system awareness between managers in South Korea's construction industry. Safety and Health at Work, 4 (4), pp. 201-209.

Zhang, Y. ,Shao, W., Zhang, M., Li, H., Yin, S., Xu, Y. (2016). Analysis 320 coal mine accidents using structural equation modeling with unsafe conditions of the rules and regulations as exogenous variables. Accident Analysis and Prevention. Volume 92, 1 pp. 189-201.

\begin{abstract}
.
The subject of this publication is to analyze the circumstances and causes of accidents at work in a selected industrial enterprise that provides services in the field of waterjet cutting and laser beam. The paper present the statutory definition of an accident at work and its basic categories (light, heavy, mortal and collective accident). It also discusses the most popular accident investigation method - the TOL method, which classifies the causes of accidents into three basic groups: material-technical, organizational and human. In the further part of the work the characteristics of the waterjet operator's work station were made, including the scope of activities, possible occupational hazards and preventive actions. Next, the results of the analysis of the circumstances and causes of accidents at work were presented. In the period from 2013 to 2018 eight accidents were reported, resulting in minor injuries, such as cuts and cuts, fracture of the phalanx, overloading of the spine, leg twisting or knee injury.
\end{abstract}

Keywords: accident at work, accident prophylaxis, examination of the circumstances and causes of the accident, waterjet operator, water jet cutting 